\title{
Building Ideological Bridges and Inventing Institutional Traditions : Festivities and Commemorative Rituals in the Fascist and Nazi Police
}

Jonathan Dunnage and Nadine Rossol

\section{(2) OpenEdition Journals}

Electronic version

URL: http://journals.openedition.org/chs/1553

DOI: 10.4000/chs. 1553

ISSN: 1663-4837

\section{Publisher}

Librairie Droz

\section{Printed version}

Date of publication: 1 June 2015

Number of pages: $67-88$

ISBN: 978-2-600-01953-8

ISSN: $1422-0857$

\section{Electronic reference}

Jonathan Dunnage and Nadine Rossol, « Building Ideological Bridges and Inventing Institutional Traditions : Festivities and Commemorative Rituals in the Fascist and Nazi Police », Crime, Histoire \& Sociétés / Crime, History \& Societies [Online], Vol. 19, n | 2015, Online since 01 June 2017, connection on 22 April 2019. URL : http://journals.openedition.org/chs/1553; DOI : 10.4000/chs.1553 


\title{
Building Ideological Bridges and Inventing Institutional Traditions: Festivities and Commemorative Rituals in the Fascist and Nazi Police'
}

\author{
Jonathan Dunnage ${ }^{2}$ - Nadine Rossol ${ }^{3}$
}

\begin{abstract}
Cet article analyse l'usage de rituels de célébration et de commémoration destinés à attacher les forces de police aux dictatures fascistes et nazies au plan idéologique et culturel. Il examine les festivités publiques telles que la Journée de la police (Festa della Polizia/Tag der deutschen Polizei), visant à démontrer l'intégration politique et professionnelle de la police dans le régime fasciste ou nazi, dans le contexte plus général de l'organisation par ces régimes de rituels très esthétisés pour renforcer la communauté nationale. Les rituels policiers, notamment ceux qui commémorent des martyrs visaient également à rapprocher policiers et fascistes/Nazis en proclamant qu'ils partageaient des valeurs et des expériences formatrices communes. Tout en mettant en question le succès idéologique de tels rituels, l'article argue que les institutions policières y ont souvent volontairement pris part afin de conforter leur présence dans l'espace public et de s'assurer un haut niveau d'estime de la part de leurs chefs politiques. Cet article montre l'intérêt des approches culturelles pour l'histoire des polices et souligne la nécessité d'une comparaison plus approfondie entre les polices fascistes et nazies.
\end{abstract}

This article analyses the employment of rituals of celebration and commemoration to ideologically and culturally bind police forces to the fascist and Nazi dictatorships. It considers public festivities such as 'police day' (Festa della Polizia/Tag der deutschen Polizei) as instruments for demonstrating the professional and political integration of the police into the fascist/Nazi regimes, in the broader context of the staging by these regimes of highly aestheticized rituals to reinforce the national community. Police rituals, notably those involving the commemoration of 'martyrs', were also employed with the intention of bringing together policemen and fascists/Nazis, by claiming that they shared common values and formative experience. While the ideological success of these rituals is questioned, the article argues that police institutions often willingly participated in them to ensure their occupation of public space and high standing in the eyes of their political masters. The

We would like to thank Tim Kirk and the reviewers for CHS for their helpful comments.

2 Jonathan Dunnage is Associate Professor of Modern European History at Swansea University, UK. He has widely researched the history of policing in modern Italy. His recent publications include Mussolini's Policemen. Behaviour, Ideology and Institutional Culture in Representation and Practice (Manchester University Press, 2012).

3 Nadine Rossol is Lecturer in Modern European History at the University of Essex, UK and Fellow of the HEA. Her current research focuses on the German police from the 1920s to the 1950s and on festive state representation in Weimar and Nazi Germany. Her publications include Performing the Nation in Interwar Germany 1926-1926 (Palgrave, 2010). 
article illustrates the importance of bringing cultural approaches to the study of police history and underlines the need for a more thorough comparison between the police forces of fascist Italy and Nazi Germany.

\section{INTRODUCTION}

Examining the repressive policy of police forces in the Third Reich and in fascist Italy has been at the core of police research for both dictatorships. While this is without doubt an important area of investigation, the public in Italy and Germany did not just encounter the police in this function. Our article investigates the employment of celebratory and commemorative rituals in the police during the Italian fascist and Nazi dictatorships. We argue that this allows a clearer understanding of measures undertaken to integrate culturally and ideologically these institutions and their personnel into these regimes and to present them as such to the public. With particular reference to the Interior Ministry Police (Pubblica Sicurezza) in Italy and the uniformed police (Ordnungspolizei) in Germany, the first part of the article analyses 'police day' celebrations (the Festa della Polizia and the Tag der deutschen Polizei) $)^{4}$, events instituted to showcase the police as pillars of their respective regimes to the general public, while the second part focuses on more intimate rituals of commemoration of fallen policemen, which, we argue, were intended as a means of creating a common culture with the fascists/Nazis.

We examine police festivities and commemorations in the broader context of fascist/Nazi rituals, with their stress on symbols and gestures, around which the sense of a national community was to be forged. ${ }^{5}$ We pay close attention to the intended messages to the masses behind those rituals which were staged as public events. Both the fascist and Nazi cases suggest that 'police day' celebrations were partly created to present the police as an institution which played a key role in the new regime, thereby also reinforcing the binary opposites of inclusion in/exclusion from the national community. Beyond the intended public impact of such rituals, our article also addresses how, and how extensively, police personnel participated in them. We analyse the themes and messages communicated during these rituals, considering them as vehicles for stressing, if not inventing, shared values and a common historical narrative between policemen and fascists/Nazis. This was particularly the case with commemoration rituals, many of which involved the joint participation of policemen and Nazis/fascists but were often more intimate in character than 'police day' celebrations. Bearing in mind that the regular police forces of neither country underwent radical changes in personnel following the rise to power of Mussolini/Hitler, the rituals aimed to make a positive statement about the political credentials of police institutions. These, at least nominally, had opposed

${ }_{4}$ For Nazi Germany, one of the first, but mainly descriptive, overviews of 'police day' is Hansen (2000, pp. 230-262).

5 For the purpose of this article, we decided to use the generic term 'national community'. In Germany, 'national community' was a key concept for the Nazi regime and heavily drawn on in Nazi rhetoric. Furthermore, as the section on Nazi Germany will illustrate, historians have also used the term as an analytical tool to explain Nazi propaganda strategies and, more recently, to understand its integrative function allowing for different ways of individual participation in this national community. In Italy, the idea of a fascist or national community was expressed by the desired integration of the masses into the 'totalitarian state', thereby creating a 'moral' community governed by one 'faith'; see Gentile (1993, p. 148). 
the fascist/Nazi movements in the past and first-hour fascists and alter Kämpfer, therefore, harboured suspicions towards them - though in practice some institutions were more hostile than others, and many individuals they employed may have ignored directives and supported the Fascists/Nazis.

In addressing the above questions, attention is also paid to the role and intentions of the police hierarchies and the fascist/Nazi governments in relation to these rituals. The results of the research undertaken suggest a realisation on the part of police institutions in both countries that they constituted, in the context of competition and rivalry with other police institutions and with organisations of the PNF and NSDAP, a means of ensuring their occupation of public space - and by extension, their membership of the national community - thus increasing their status and prestige, even when they were not necessarily convinced by the underlying ideological messages. Moreover, the police rituals should be considered in the context of the particular significance which both regimes gave to the armed forces, which potentially diverted attention, prestige and funds away from the police. ${ }^{6}$ As important as it might have been to communicate a certain message to the public, it was equally important to present the police to the regime and party organisations as an essential force within the state's security institutions.

These issues are considered in the context of two broader objectives underpinning our article. Firstly, the research undertaken for this study combines the disciplines of police history and cultural history. While the repressive measures undertaken by the police forces of dictatorships clearly need to be considered, the notable energy which dictatorships put into the employment of symbols and public festivals seem to be forgotten when the police forces are examined. ${ }^{7}$ Greater focus on this approach here represents an extension of the scope of cultural history studies which until now have mainly focused on the "fascistization'/ Nazification of civil society as opposed to state institutions. ${ }^{8}$ Secondly, though we are unable to undertake a comprehensive study, this is an opportunity for a move in the direction of a more thorough comparison between the police forces of fascist Italy and Nazi Germany, incorporating the important link between police history and cultural history. Such a comparison is warranted on account of the overriding commonality of ideological aims characterising the two 'fascist' regimes, despite some structural distinctions between their police systems. ${ }^{9}$

6 In Nazi Germany, for example, the police faced recruitment difficulties, as young people preferred to join the armed forces.

7 See Rossol (2013, pp. 319-30). For Germany, more general criticism that police history is not up-todate with new methodological approaches in the writing of history is voiced by Weinhauer (2003, pp. 378-83). Sociologists were much quicker to examine symbols and police culture as part of policing. See Loader (1997, pp. 1-17); Behr (2000, 2006).

8 For studies of the use of symbols and festivities in fascist Italy, see Gentile (1990, pp. 229-51); Falasca-Zamponi (2000). For Nazi Germany, see Vondung (1972); Hermann, Nassen (1994); Reichel (1991) suggests in his study that Nazi festivities were meant as diversion from the brutal policy of the regime.

9 For a comparative overview of policing which includes the topic of political integration, see Dunnage (2006, pp. 93-122). Research on the relationship and co-operation between the Nazi and fascist police has been published by Bernhard (2009, pp. 407-24). Within the historiography of repression under the individual regimes, approaches to the political integration of the police include Dunnage (2012); Matthäus et al. (2003); Schulte (2009). For recent local studies of the Nazi police see, for example, Dams et al. (2007); Schloßmacher (2006). 


\section{THE FESTA DELLA POLIZIA AND THE TAG DER DEUTSCHEN POLIZEI}

Starting in 1928, the Festa della Polizia ${ }^{10}$ which celebrated the Italian Interior Ministry Police, took place annually on 18 October until 1939. Although smallscale events, often within the confines of the police station or training school, were staged throughout Italy, the main celebrations took place in Rome, characterised by monumental displays of skill and technological advancement in the presence of Mussolini, government ministers and representatives of institutions of the state, fascist dignitaries, representatives of the armed and police forces, as well as police delegations from other nations. Those taking place at the Villa Glori hippodrome in the capital in October 1932 commenced with an inspection of the Metropolitan Police by Mussolini, during which the fascist leader decorated officers and officials for acts of bravery. This was followed by a parade past Mussolini, his right arm raised in the Roman salute, of units of guards with police dogs, on bicycles, on motorcycles, on horseback and in armoured vehicles. ${ }^{11}$ In 1933, following the morning parade in the capital, cadets of the police training school at Caserta joined the agenti of the Metropolitan Police for an afternoon of displays of gymnastics, fencing and wrestling, a demonstration of the training of police dogs, and performances of daring feats on motorbikes and horseback. ${ }^{12}$ Several other types of rituals were incorporated into these events, as will be illustrated below. Mussolini's presence at the Festa della Polizia, and the fact that this was the first annual public celebration of the Interior Ministry Police, undoubtedly signalled the importance which the regime gave to this arm of the Italian forces of law and order.

Allegedly conceived by Arturo Bocchini, Mussolini's Chief of Police from 1926 to $1940,{ }^{13}$ the Festa della Polizia was framed with a view to 'educating' and mobilizing the public in various ways, but it was equally intended as a means of enhancing the professional loyalty and, to some extent, the ideological commitment of police personnel. The celebrations formed part of an 'aestheticisation of politics' operated in all walks of fascist society, in which the employment of symbols, uniforms and rituals were conceived as a means of reinforcing a sense of belonging to the national community. ${ }^{14}$ They should also be considered in the broader context of Mussolini's involvement of the armed forces as an instrument of propaganda for the creation of mass consensus around the image of a powerful, heroic and combative nation. ${ }^{15}$ In this regard, the Festa della Polizia functioned alongside a large number

10 Research on the Italian police contributing to this article was partly financed by a British Academy Small Research Grant. The present analysis of the Festa della Polizia and other rituals develops a theme previously examined at length in Dunnage (2012, esp. Chapter 2).

11 'La festa della polizia', Il magistrato dell'ordine, 1932, 9, pp. 171-73. Footage of the Festa della Polizia, conserved by the Archivio Storico Luce, Rome, may be viewed on-line http://www. archivioluce.com/. For the 1932 celebrations, see Giornale Luce B0157.

12 'La festa della polizia', Il magistrato dell'ordine, 1933, 10, pp. 165-68; Giornale Luce B0355 [http :// www.archivioluce.com/].

13 Documentation relating to this is scarce, but an article in the police journal Il magistrato dell'ordine refers to 'police day conceived and desired by His Excellency Bocchini'. See 'La festa della polizia', Il magistrato dell'ordine, 1933, 10, pp. 165-68.

14 For a detailed discussion of this, see Falasca-Zamponi (2000, Chapter 3).

15 For a discussion of this aspect of fascist propaganda, see Oliva (1992, p. 187). 
of parades and ceremonies involving the armed and other police forces, as a means of emphasising fascist Italy's military strength and warrior qualities.

While the form of the Festa della Polizia celebrations remained more or less unchanged from 1933, there is evidence to suggest that from the mid-1930s onwards they were framed with a view to stressing the imperialist achievements of the regime in the context of the invasion of Abyssinia in 1935. The celebrations also reflected a new era of international fascism, marked by growing alignment and cooperation between fascist Italy, Nazi Germany, and other right-wing regimes. It is no coincidence that the head of the Nazi police, Heinrich Himmler, regularly attended the Festa della Polizia. ${ }^{16}$ The event took on a tangibly militaristic quality with the adoption of the Roman step (goose step) for processions from 1938. If representations of the Festa della Polizia stressed the ability of the police to defend the nation from internal threats, an article of 18 October 1936, published in the Genoese daily newspaper, Il giornale di Genova, and reproduced in the police journal, Il magistrato dell'ordine, noted that the celebrations took on a new significance, "because on this occasion they fall precisely in year one of the Empire, when all energies, all forces and all arms of the Fatherland and fascist State are mobilized to give the Empire we have acquired a destiny worthy of the tradition of Rome". Moreover, implying that the police were not to be considered less important than other armed forces in the new imperial context, the article stressed that: "Now that the activities of the State and of the Nation have been transferred to the sphere of the Empire, the Police, too, indeed, above all the Police will have to undertake functions and responsibilities of major significance, in order to contribute with whatever means are available to the exploitation and defence of the Empire". ${ }^{17}$

Throughout the period in which it was staged, the Festa della Polizia aimed to showcase the Interior Ministry Police to spectators at the event and to the wider public (as evident in newspaper reports and newsreels shown at cinemas), as an institution which, following Benito Mussolini's rise to power, had been reinvigorated into a modern, technologically advanced, and highly powerful organ of the state, manned by athletic and professionally skilled men, fully capable of protecting the Italian nation and its citizens, and as such the envy of foreign police forces. This was conveyed in above-cited article in the Giornale di Genova. The fascist police now had at their disposal means which only a few years previously had been the pride of police forces beyond Italy - indeed, it was now the foreign police which studied the Italian police. ${ }^{18}$ References in the article to the 'reinvigoration' and 'reorganization' of the police, should be considered in the context of the lack of prestige enjoyed by the Interior Ministry Police under the Liberal state, particularly when contrasted to their main rival, the Carabinieri (military police) and the negative associations in the public mind regarding law and order maintenance during the Liberal period. ${ }^{19}$ The rise of fascism, it was implied, had allowed the police to enter a new highly positive

16 See, for example, the article on the participation of Himmler, alongside the head of the SA, Reinhard Heydrich, and the head of the Ordnungspolizei, Kurt Daluege at the 1936 celebrations. 'I Capi della Polizia Tedesca a Roma', Il magistrato dell'ordine, 1936, 13, p. 135.

17 Giulio Altamura, 'Una forza dell'Impero', Il giornale di Genova, 18 October 1936, reproduced in Il magistrato dell'ordine, 1936, 13, p. 134.

18 Ibid.

19 For a more detailed discussion, see Dunnage (2012, pp. 9-15). 
phase of their existence in which they were no longer considered a second-class organ of the state.

The Festa della Polizia was employed, therefore, to stress the new prestige which the Interior Ministry Police enjoyed under fascism, having been identified as the principal security organ to be entrusted with the task of defending the regime. In this regard, the inspiration behind the event was the celebration of the anniversary of the 'creation' in 1925 of the Agenti di Pubblica Sicurezza (though in real terms this was a partial re-constitution of the police force of the Interior Ministry), which marked the relegation of the Carabinieri to a secondary position in the overall hierarchy of policing during the fascist period. ${ }^{20}$ Moreover, as the article of October 1936 implies, the presence of representatives of the police forces of other countries at the celebrations was used to propagandise the international reputation of the Interior Ministry Police, along the lines that in the past the Italian police had had to look up to foreign police forces; now it was the foreign police who had to learn from them. The oral commentator of newsreel footage of the 1937 celebration reinforced this notion in proclaiming how: 'The German, Austrian, Hungarian, Portuguese, Yugoslav and Albanian police delegations watch the superb spectacle and the procession of six thousand men carrying the most advanced arms and equipment' ${ }^{21}$

The Festa della Polizia and the rituals which these entailed aimed to present a police force which was ideologically integrated into the fascist regime. ${ }^{22}$ This is evident in the display of fascist gestures, such as the Roman salute, and in the presence of representatives of the government and Fascist Party, with Mussolini officiating at the main event in the capital. As part of the celebrations in Rome, provincial police chiefs (Questori), wearing the Party black shirt (and from 1938 the fascist ceremonial uniform for state officials) were received by Mussolini at his headquarters in Palazzo Venezia. Their presence in the capital was also an occasion for other rituals of devotion to the regime. After attending the Festa della Polizia on 18 October 1933, they paid an official visit to the Exhibition of the Fascist Revolution the following morning, and to the Tomb of the Unknown Soldier and the Altar of the Martyrs of Fascism in the afternoon. ${ }^{23}$ We may surmise that the rituals characterising the Festa della Polizia aimed to symbolically empower the national community, which benefited from the force and protection afforded by the new 'fascist' police, as evident in the display of large numbers of men and of technological advancement, combined with demonstrations of ideological devotion.

There is evidence that the Festa della Polizia was also an occasion for publicising financial donations to national causes by police personnel, particularly in the wake of the Abyssinian campaign, which had seen mass rituals of donations of gold

20 There is some continuity in personnel, structures and tasks between the Agenti and previous police forces of the Interior Ministry. Such continuity was temporarily interrupted in December 1922 by the abolition of the then Interior Ministry force, the Regie Guardie (Royal Guard), and the entrusting of their tasks to a special unit of the Carabinieri (though personnel of this unit came from the disbanded Royal Guard); but what in many respects marked a re-constitution of the police force of the Interior Ministry in 1925 was propagandised as the creation of a 'new' police.

21 Giornale Luce B1184, 20 October 1937 [http ://www.archivioluce.com/].

22 In this regard the ban on Party membership since 1925 was lifted for Interior Ministry Police officials and office employees in 1932 and for Agenti di Pubblica Sicurezza in 1934. Thereafter, membership was essential for admission to the police or promotion.

23 'I Questori del Regno', Il magistrato dell'ordine, 1933, 10, p. 168. 
(including by police personnel) to counter international sanctions. ${ }^{24}$ Such gestures undoubtedly served to enhance the image of a force which played an active part in the national community, which exceeded the traditional confines of policing. As part of the celebrations in 1936, for example, the Questore of Rome formally presented to the Federal Party Secretary a contribution of 19,000 Lire collected from among members of the Roman police for the Good Works Association (Ente Opere Assistenziali) set up by the Party in 1931. Underlining the narrative of ideological integration around which the police were being constructed, the Federal Secretary officially thanked the Roman police for their "gesture of fascist solidarity (...) towards those in need" ${ }^{25}$ It is arguable, however, that donations did not feature as prominently as they did in rituals of the Nazi police. This reflects the broader scenario in which such rituals, though founded under both regimes upon the idea of instilling a spirit of material renunciation and sacrifice, were practised more systematically in Nazi Germany. ${ }^{26}$

The Festa della Polizia was also part of a broader strategy for representing the police to their own personnel and, arguably, bonding them to the fascist regime, though there is some question as to how seriously this latter aim was intended, at least from the perspective of the police leadership. The repeatedly stressed message which accompanied the event, as evident in speeches and reports in Il magistrato dell'ordine, was that the Interior Ministry Police owed their new fortunes to Mussolini, since his rise to power and the creation of the fascist regime had led to a major reform of their institution, which was now entrusted with responsibilities of 'national' importance. This message partly played on the professional frustrations which the police had suffered under the Liberal state. The event itself, which marked the first time the Interior Ministry Police were publicly celebrated, was framed as a sign of the unprecedented consideration which the fascist regime had for the Interior Ministry Police. On the occasion of the first celebrations in 1928, Il magistrato dell'ordine declared that the event signalled : "the official, solemn and public consecration of the new organ of the state police, (...) the day in which the Administration of Public Security emerges from the turbid semi-darkness in which it has lived until now". ${ }^{27}$ It was equally important to convey to police personnel the public support for their institution which had been achieved under Mussolini. This was undoubtedly one of the intentions behind the reproduction in the police journal of an article on the 1933 celebrations originally published in the Roman daily $I l$ messaggero; the article noted the incessant enthusiasm of the exceptionally large number of spectators who had crowded into the Villa Glori hippodrome to watch the event. The editor's comment which followed stressed among other things the

24 Documents in the files of the Interior Ministry Police show how, like the rest of the population, police personnel were 'mobilized' to give up their wedding rings. The Questore of Siena, for example, invited the men under his command to undersign their willingness to offer gold and silver to the national cause (Archivio di Stato di Siena, Questura, F.161, Cat E.3, sf. Raccolta fra il personale di PS d'oro e di argento di offrire alla Patria).

25 'Cospicua offerta della Questura di Roma all'E.O.A', Il magistrato dell'ordine, 1936, 13, p. 134.

26 For a detailed comparative analysis, see Terhoeven (2005, pp. 59-93). She argues that while the Nazi regime engaged the public in regular donations to the Winter Relief Fund, in Mussolini's Italy donation campaigns mainly focused on mobilising the nation in times of war.

27 'XVIII Ottobre 1928', Il magistrato dell'ordine, 1928, 5, pp. 173-74. 
role of the police in protecting the public, defending the vulnerable and fighting injustice. ${ }^{28}$

The fascist regime's major enhancement of the profile of the Interior Ministry Police was also stressed in police literature reflecting upon the Festa della Polizia of October 1932, which coincided with the tenth anniversary of the March on Rome. On this occasion, Mussolini publicly proclaimed himself supreme commander of the Interior Ministry Police. In commenting on this, Emilio Saracini, director of Il magistrato dell'ordine, exclaimed from the pages of his journal that this was a huge honour for the police. In referring to the fact that it was Mussolini in person who awarded medals during the celebrations, he added that never before had an Italian Head of State deigned to personally decorate the chest of valiant members of the police. ${ }^{29}$ The homage which such narrative paid to Mussolini nevertheless incorporated mixed and contradictory messages. While the Festa della Polizia was an occasion for officially conveying the unity of the Italian police forces, ${ }^{30}$ it indirectly drew attention towards historic rivalries between different police forces by stressing the institutional importance which fascism entrusted to the Interior Ministry Police.

It should be stressed that the Interior Ministry Police may have differed from the fascist government in regard to the intended significance of displays of devotion to fascism which characterized the Festa della Polizia and also more intimate rituals of commemoration involving the police (see below). The Chief of Police, Bocchini, in contrast to Himmler, a non-Party figure, though sympathetic towards the regime, was intent on shielding the institution from excessive ideological encroachments. This should be considered in the broader context of Bocchini's ability to maintain the professional and cultural autonomy of the police by accepting a formal 'fascistisation' of the police environment, including obligatory Party membership from 1932, whilst fighting off attempts at more substantial ideological integration. ${ }^{31}$ In the absence of documentation illustrating more clearly how much influence Bocchini had over the running of the Festa della Polizia and his possible liaisons over this with Mussolini, who evidently took on a pro-active role on several occasions, we may surmise that Bocchini encouraged displays of homage to fascism characterising this and other events in the belief that they would not substantially influence the internal culture of the police. Indeed, such displays would help to maintain the high status of the Interior Ministry Police and at the same time maintain their ideological independence.

An analysis of the Festa della Polizia and its comparison with the more practical aspects of daily policing during the fascist dictatorship brings to light the strongly rhetorical and spectacular character of the celebrations. The educative aspects of the event are clearly stated in the first celebration in 1928, with Mussolini ordering the

28 Il Messaggero, 19 October 1933, reproduced in 'La festa della polizia', Il magistrato dell'ordine, 1933, 10, pp. 165-67.

29 Emilio Saracini, 'Nel decennale fascista', Il magistrato dell'ordine, 1932, 9, p. 170.

30 Altamura's article 'Una forza dell'Impero' in the Giornale di Genova, cited above, stressed, for example, the Interior Ministry Police's 'fraternal collaboration' with the regime's other police forces.

31 In 1936, for example, Bocchini managed to prevent police personnel from joining the Party Militia en masse, following the Fascist Party's announcement that all its members were eligible for this. See Archivio Centrale dello Stato, Ministero dell'Interno, Direzione Generale di Pubblica Sicurezza, Divisione Personale di Pubblica Sicurezza, Affari Generali, versamento 1961, b. 20, f. Funzionari ed agenti non debbono essere iscritti alla MVSN. 
attendance of members of the Balilla youth organisation. ${ }^{32}$ Representatives of youth and after-work organisations were commonly among the spectators on these annual occasions. ${ }^{33}$ Yet, there is little sense that the Festa della Polizia was employed to establish a closer rapport with citizens or a practical understanding of how the police worked (for example, through the provision of detailed information relating to policing techniques or the type of service which the police provided to the public). The Festa della Polizia may have helped to reinforce some kind of image in the minds of the public, particularly that of an impressionable young age, of a powerful, if not intimidating, arm of the state which was at one with fascism. In many respects, however, the displays of professional skill, technological innovation and devotion to the regime which characterised the event were distant from the public's daily encounters with the police on the streets and in the police station. Inspection and investigation reports dating back to the 1930s and early 1940s often suggest disorganisation, poor training, archaic rather than modern policing procedures and facilities, the increase in abuse of powers to the detriment of citizens, as well as a comparatively elderly rather than rejuvenated personnel, particularly in the provinces. ${ }^{34}$ In this regard, a fascist police official argued in 1935 that the displays of skill performed by the Metropolitan Police at the celebrations in Rome could not be emulated at celebrations taking place in other towns. ${ }^{35}$ Nazi Germany also staged festivities to promote a friendly and professional image of the police to the public and to present policemen as pillars of the National Socialist state, but the 'Day of the German Police' (Tag der deutschen Polizei) happened less regularly than its Italian counterpart. Planned as an annual event, it was first held on 18 and 19 December 1934, but postponed numerous times afterwards until 1937. From then onwards, the Tag der deutschen Polizei took place almost every year (with the exception of 1938) until 1942. ${ }^{36}$ The gap in the mid-1930s can most likely be attributed to the Propaganda Minister's belief that there were too many festivities of this kind. For 1938, Joseph Goebbels refused to allocate a day to the police because he had already granted one to the military. The head of the Ordnungspolizei, Kurt Daluege, was not impressed by this decision as he saw the event as a significant propaganda opportunity for his force. Clearly, Daluege's reaction reflects his concerns about the prestige and status of the police which he saw as compromised by Goebbel's actions and falling well behind that which the military enjoyed in the Third Reich. ${ }^{37}$

Initially staged throughout Germany, with celebrations in the capital as well as in other German cities and towns, the Tag der deutschen Polizei extended to

32 'XVIII Ottobre 1928', Il magistrato dell'ordine, 1928, 5, pp. 173-74.

33 Representatives of the Fasci Giovanili, Balilla, Piccole Italiane, and after-work representatives of the Party district headquarters were present at the 1933 celebrations in Rome. See 'La festa della polizia', Il magistrato dell'ordine, 1933, 10, pp. 165-68.

34 Reports of regular inspections and a large number of investigations of police stations and their personnel can be accessed at the Archivio Centrale dello Stato, Ministero dell'Interno, Direzione Generale di Pubblica Sicurezza, Divisione Personale di Pubblica Sicurezza, Affari Generali.

35 Ulderico Caputo, 'La Polizia e lo Sport', Il magistrato dell'ordine, 1935, 12, p. 71.

36 Hansen (2000, pp. 244-62).

37 Bundesarchiv Berlin (herafter BArch Berlin), R19/389, (no page number), letter K. Daluege to H. Himmler, 25.7.1938. 
Vienna in 1939 and to some of the other territories which the Nazis occupied. ${ }^{38}$ With the outbreak of the Second World War, the German 'police day' also became more militaristic. If, before the war, posters stressed the civilian character of the police as helpful and preventing dangers like robberies, traffic accidents or house fires, the posters produced in 1941 and 1942 illustrated the new role of the police at the front and demonstrated their close link to the army. ${ }^{39}$

One of the main aims behind the Tag der deutschen Polizei was to emphasise the police's close links to the public and this was presented as being specific to the Third Reich, contrasting positively against the Weimar years. The police journal Der deutsche Polizeibeamte stated: "Nothing can express the close relations of the police better than this Police Day celebrated on December 18-19 as part of the Winter Relief Fund. The times are over in which the police acted as Knüppelgarde degraded by the previous system that governed without and against the people. In the National Socialist State the police are part of the people". ${ }^{40}$ While this remained the main official motivation given for the Tag der deutschen Polizei (concealing greater concern to ensure the force's status as a member of the Nazi state's security agencies), the police did use some of the festivities to demonstrate new developments and important shifts within the police to the public. The 1937 event, following the nationalization of the police in 1936 and the incorporation of the fire brigades into the Ordnungspolizei, aimed to reflect these developments with a particular stress on cooperation between policemen and firemen ${ }^{41}$ It is obvious that the day was also meant to stress a unified police which included uniformed forces of the entire country. At the same time, the official guidelines suggest that, although the activities were grounded in an official framework, local police stations were to be given leeway in organising them according to their suitability to local circumstances. ${ }^{42}$

The activities that characterised the Tag der deutschen Polizei were not new to the police as they resembled promotional efforts carried out from the mid-1920s onwards to improve the image of the police, especially the Prussian police force. ${ }^{43}$ In the Weimar as well as in the Nazi years, these activities included public donations of meals to the poor, the staging of sporting events, public concerts, exercises using dogs and horses, as well as games for children. ${ }^{44}$ The Tag der deutschen Polizei continued and expanded these types of activities. In some areas police stations were decorated, parades were held and riding on horseback was organised. ${ }^{45}$ The official

38 BArch Bildarchiv, Plakt. 003-056-064, Feb.1942 Slovenia.

39 BArch Bildarchiv, 1939: Plakt. 003-016-050, 003-016-047/ 1941-42, Plakt. 003-016-121, 003-016122, 003-025-007.

40 Aufrufe zum Tag der deutschen Polizei, Der deutsche Polizeibeamte, 2, 15.1.1935, p. 42.

41 BArch Berlin, R19/389, Rundschreiben d. Reichsführer SS und Polizei nr.108, December1936.

42 Ibid.

43 For the Weimar Republic, the Great Police Exhibition in Berlin in 1926 illustrates the official efforts to improve the image of the police in the Weimar years stressing the police's role as friendly and helpful.

44 For Nazi Germany, see the recommendations made by leading police officials for the programs of the 'police day' in BArch Berlin, R19/389 (no page number), Chief of the Prussian gendarmerie to the Reich Minister of the Interior. 15.10.1934 and BArch Berlin, R19/389, Notice nr.108 Dec.1936 regarding Tag der deutschen Polizei.

45 Images and short reports on different activities featuring in the 1934 Tag der deutschen Polizei can be found in a book edited by Daluege (1934). Newspapers and journals published similar images and stories on the success of the day. 
directives for the police festivities in 1937 suggested the incorporation of exhibitions of police equipment, demonstrations of police dog skills, and police parades, and local events such as church services, commemorative rituals, public concerts, and sports performances. However, the directives clearly paid attention to the public's enjoyment of the programmes on offer stating that "everything must be done in such a way that the interest of the public continuously increases". ${ }^{46}$ A great effort was directed at trying to cater for public taste and offering events that actually reached the general public.

In striking contrast to the Italian festivities, the Tag der deutschen Polizei was linked to raising money for the Winter Relief Fund. This involved uniformed policemen holding out collection tins to members of the public. In Nazi propaganda, the representation of policemen as pillars of the Nazi state and their obligation to collect money belonged together. Newspaper articles as well as senior police officials pointed out that the police, as part of the national community in the Nazi state, contributed to the well-being of this community by helping to support the poor. ${ }^{47}$ While the police had been involved in charitable work before, for example helping to provide meals for poor children in the winter months in the early $1930 \mathrm{~s},{ }^{48}$ the particularly pronounced collections in 1934 and the following years went hand in hand with a shift from a stress on charity to emphasis on sacrifices for the national community as part of the Winter Relief Fund's strategy. ${ }^{49}$ Not everyone was happy with this explicit role for the police. High-ranking officials of the Prussian Ministry of the Interior warned in late 1933 that uniformed policemen collecting money could be seen as exercising police pressure to donate money and that this would counteract the important stress on voluntary donations. ${ }^{50}$ Similar arguments were put forward in early 1942 when the head of the Ordnungspolizei Daluege was criticised for letting policemen go from house to house asking for donations. ${ }^{51}$ There was limited leeway for refusing to participate in this display of commitment to the National Socialist national community especially for policemen. Public media coverage of the best activities of the 'day', competitions among police stations for the most funds collected and a mandatory withdrawal of a donation from the policemen's salaries allowed for little disagreement from within the police. ${ }^{52}$ While policemen found it difficult to avoid police festivals, the events were not imposed on the German public. Those who did not want to take part in the activities offered could find ways of

46 BArch Berlin, R19/389, Rundschreiben nr. 108, December1936.

47 Der deutsche Polizeibeamte, 15.1.1935, 2, p. 42; 'Der Tag der deutschen Polizei' and 'Zum Tag der Deutsche Polizei', Der deutsche Polizeibeamte, 15.3.1936, 6, p. 210, p. 245.

48 'Die Polizei hilft', Die Polizei, 5.2.1931, 3,p. 49; 'Kinderspeisung durch die staatliche Polizei Gladbach',Preußische Polizeibeamten Zeitung, 13.2.1932, 7, p. 122; 'Winterhilfe der Stadt Hannover', Preußische Polizeibeamten Zeitung, 6.2.1932, 6, p. 103; 'Kinder in Not', Preußische Polizeibeamten Zeitung, 23.1.1932, 4, p. 68; 'Die Polizei hilft: Kinderspeisung durch die Schupo in Oberhausen', Die Polizei, 20.6.1931, 11, p. 273. For the beginning of winter aid in the Weimar Republic, see Tennsted (1987, pp. 157-80).

49 See the piece by Terhoeven (2005), though she does not explicitly concentrate on the police.

50 BArch Berlin, R19/389, Regierungsrat Thielen, 6.11.1933.

51 BArch Berlin, R19/389, Letters between Daluege and Schwarz.

52 For the money collected, see Daluege (1934, pp.134-35); BArch Berlin R19/389, letter to Himmler 21.1.1937; 'Dank an die deutsche Polizei', Der deutsche Polizeibeamte, 15.1.1935, 2, p. 42. 
avoiding to do so altogether or only get involved by fulfilling the minimum of what was believed to be expected from them.

While the activities which policemen carried out on the Tag der deutschen Polizei - ranging from the more spectacular sports performances or car racing to explaining to children the dangers posed by traffic and telling adults how to keep their flats safe from burglaries - were reminiscent of earlier years, the broader political framework in which they took place did influence the events. Such activities as collecting and donating for the Winter Relief Fund allowed both direct participation in the Nazi community and the communication of such participation to the public. This was true for policemen and true for those donating money or buying a badge with the Tag der deutschen Polizei slogan. Petra Terhoeven suggests in her analysis on Winter Relief Fund events more generally that the change from charitable donations to sacrifice which the Winter Relief Fund emphasised helped to prepare society for times of war. ${ }^{53}$ As much as collections during the Tag der deutschen Polizei allowed for participation in the Nazi community, they also communicated exclusion, especially given the involvement of security forces who had communicated very clearly for whom they still were 'friends and helpers' - as the slogan of the celebrations of 1937 suggested. Heinrich Himmler formulated it for the 1934 event like this: "The police in Nazi Germany want to be seen as friend and helper of the German people but criminals and enemies of the state should consider the police as their worst enemy... We are convinced that every German comrade who considers the policeman as a friend and helper will happily make his/her sacrifice at the Day of the German Police". 54

Similar to the situation in Italy, the great activity during the Tag der deutschen Polizei, that took place in the German capital but also in a number of other cities and towns, did not reflect everyday experiences regarding the visible presence of the police in German society. Difficulties in recruiting young men into the police who preferred a career in the army meant that Nazi Germany's uniformed police never achieved the same levels of manpower which they had during the Weimar years. ${ }^{55}$ The suggestion that the police had eyes and ears everywhere was a myth - not only for the Gestapo - and perhaps this helps to explain some of the importance which high-ranking police officials gave to the Tag der deutschen Polizei. Demonstrating the police's successful involvement in Winter Relief Fund collections on a day solely dedicated to the police maintained the force's significance not just as pillar of the Nazi community but also as an essential player within the state's security forces. Furthermore, it allowed the police to encourage the public to take part in their activities and in so doing offered opportunities for involvement and participation giving the abstract concept of the national community a more tangible form. Recent research on the Nazi national community (Volksgemeinschaft) suggests that it was not just a propaganda slogan imposed on the German public but filled with meaning(s) by different sections of society through participation and appropriation of parts of this concept when it seemed appropriate or useful. ${ }^{56}$ Police festivals

33 Terhoeven (2005, pp. 86-88).

54 Daluege (1934, p. 20).

55 Schmidt (2008, p. 439).

56 Wildt (2007) suggests that the Volksgemeinschaft was envisaged and acted on from below and was not just a top down concept. Recent edited collections have broadened the focus on the participative 
offered this opportunity to substantiate this slogan with participatory activities that could generate a consensus behind a seemingly abstract concept.

\section{COMMEMORATIVE PRACTICE AND INVENTING TRADITIONS}

Commemorative practices and rituals of remembrance characterising the fascist/Nazi police, whether part of or separate from the Festa della Polizia/Tag der deutschen Polizei, had a greater internal focus in their efforts to create an institutional tradition and a historical narrative which was at one with the ideologies of emerging political forces. In Nazi propaganda, it was the re-interpreting of police deaths during the Weimar years that was seen as creating an institutional identity that could facilitate integration into the Third Reich. This was done at a time when police authority and the force's monopoly on violence was shared, questioned and negotiated between the police and Nazi organizations like the SS and the SA. When the National Socialists came to power, it quickly became clear that the police force of the Weimar Republic needed to be incorporated into the new political system. ${ }^{57}$

To successfully communicate the integration of a police force that until recently had served, at least nominally, to protect Germany's first democracy against its opponents, the National Socialists followed simple principles in their creating of a common founding story that stressed the similarities between them and the pre-1933 police. Presenting the Communists as mutual enemies, supported by the suggestion that police work had been carried out in (silent) opposition to the leaders of the Republic, was at the core of most of the commemorative practices and their interpretations. Both elements facilitated the message that Weimar Germany's policemen and Weimar Germany's National Socialists had much in common. This was an important point as it did not just help the police to smoothly transfer from one political system into the next but it was also aimed at old Nazi fighters (alte Kämpfer) who were irritated by the seemingly effortless integration of the former representative of the Weimar state. In November 1936, an article in the police journal Die Polizei entitled 'Monuments of German Police History' chronologically summarised the occasions "when policemen had defended the fatherland". According to the article, in the early 1920s the police had fought against the threats of the red Ruhr army, movements of separatism in the Rhineland, and uprisings in central Germany. In Hamburg, in October 1923, seventeen policemen had died in fights with communists. The period spanning the mid-1920s and 1933, so the article claimed, had been characterized by "individual communist terror attacks against the police". ${ }^{58}$

In addition to these reinterpretations, the Nazis tried to present their state as the first one to truly honour the sacrifices and dangers of the work of the police. In fact, the Third Reich recognized the work of the police more publicly while, at the same time, involving a number of new organisations in tasks that had originally been only

element of the Volksgemeinschaft without creating a consensus among historians concerning the usefulness of the term as an analytical tool. For an overview on the recent debates see SchmiechenAckermann (2012, pp. 15-36).

57 For an insightful focus on commemorative practices regarding the police in the Ruhr area, see Schmidt (2008, pp. 387-94).

58 'Mahnmale deutscher Polizeigeschichte', Die Polizei, 5.11.1936, 21, pp. 442-44. 
carried out by the police. The first state funeral in Nazi Germany was for an SA man, Hans Maikowski, who had been killed together with a policeman, Josef Zauritz, on the night of 30 January 1933 when an SA group was attacked by communists. While the focus was mainly on the SA man, Joseph Goebbels wrote that "for the first time the SA and the police are on the same front". ${ }^{59}$ In late 1933, the Prussian Minister of the Interior initiated a 'Golden book for fallen police officers' in which their names, ranks, dates of birth and death, photographs and a brief description of the cause of death were to be listed. The book also included the names of members of the auxiliary police, SA men who were recruited in the first weeks after Hitler's coming to power to support the police. ${ }^{60}$ Again, we see the attempt to commemorate policemen and members of Nazi organisations side by side. The book's entries started with police deaths in 1918 and were often quoted in police journals. This reminds us of how the use of books for those who had fallen in the First World War and the military also had a tradition in some police forces. ${ }^{61}$ By 1936 the 'Golden book for fallen police officers' included the names of 678 policemen and was called "a document of the silent heroism of the German police". ${ }^{2}$

One of the key events of Nazi history politics (Geschichtspolitik) regarding police history was the remembering and reinterpreting of the killing of police officers Paul Anlauf and Franz Lenk. On 9 August 1931, both were shot by communists in Berlin's Bülow square - the area was a communist hotspot and location of the Communist Party headquarters. The killings seemed to have been planned and deliberate, presented as revenge for killings of three workers. Despite great efforts in terms of resources and manpower, Berlin's police did not manage to arrest the murderers. For the Nazis, these killings could be easily integrated into their anti-communist narrative. ${ }^{63}$ The event found its symbolic representation in a police monument unveiled at the location of the killings in September 1934. By that time, the square had already received the name of the SA martyr Horst Wessel. The monument was four meters high and there were plans to erect another monument to commemorate Wessel in close vicinity. ${ }^{64}$ The former was dedicated to "the police officers Anlauf and Lenk who were spinelessly killed here by communists and to all fallen police officers who died loyally fulfilling their duty". Unlike commemorative signs for the police that often consisted of a boulder (much in line with remembering the war dead), this monument showed two bronze figures, one lying down and one standing, bearing the equipment and wearing the uniforms of police officers.

Swastika flags, speeches and the presence among others of the head of Berlin's police von Levetzow, the Reich Minister of the Interior Frick, Kurt Daluege, as well as sections of the police, the fire brigade and the SA turned the ceremony into

59 Die Polizei, 20.2.1933, 4, p. 77; 'Polizeibanner auf Halbmast', Preußische Polizeibeamten Zeitung, 4.2.1933, 5, p. 127; 'Gedenktafel für Polizeiwachtmeister Zauritz', Die Polizei, 20.12.1933, 24, p.569; Goebbels cited in Ackermann (1990, p. 108).

60 The book was kept at the police institute Charlottenburg. 'Goldenes Buch für gefallenen Polizeibeamte', Die Polizei, 20.8.1933, 16, p. 384. Interestingly, the Metropolitan Police introduced a similar book in 1935 (and dated it back to 1920). See also RdErl d. PMdI, 29.6.1933 in Ministerial Blatt für die preußische innere Verwaltung, 5.7.1933, 94, 36.

61 P. Riege, 'Aus vergilbten Aktenblättern', Die Polizei, 5.10.1927, p. 408.

62 Koschorke (1936, p. 154).

63 See the article by Aly (1995, pp. 549-62) who mainly examines the court trails that followed.

64 Saehrendt (2004, pp. 140-44). 
a well-attended event. Particularly the connection between the police and the SA was stressed. ${ }^{65}$ The Nazi journal Der deutsche Polizeibeamte stated: “...Don't we have to pay our respect to almost 500 fallen policemen, almost 200 of whom died in the direct fight against Marxists? They were upright German men with German blood in their veins...All of them would have loved to have experienced the day when the Führer's call united them to one German front. They would have followed loyally in Adolf Hitler's ranks... Horst Wessel, like the great number of policemen, died loyally for the resurrection of the country and for the unity of its people". ${ }^{66}$ Commenting on the location, the head of Berlin's Schutzpolizei Dillenburger found that the monument represented state authority in an area that used to be dominated by enemies of the state. Indeed, the renaming of the square, the occupation of the former KPD headquarters, the erection of the police monument, alongside a monument for Horst Wessel (unveiled at the end of 1936), and the tearing down of a number of housing blocks in the area stood for a complete change of urban space there. ${ }^{67}$ At the same time, the terror directed at the political left meant that the Nazi police state was not just winning on symbolic grounds.

Not surprisingly, it was this Berlin monument that was used for commemorative rituals in the capital, in particular on the occasions of the Tag der deutschen Polizei which started with a commemoration of the dead. ${ }^{68}$ Moreover, representatives of foreign police forces visited the site to pay their respects. ${ }^{69}$ However, in contrast to the great attention given to the re-interpretation of past events in numerous written pieces, the carrying out of commemorative practices was left to individual police forces. Hamburg's police had commemorated those seventeen police officers killed in the city's communist uprising in October 1923 from the mid-1920s onwards. The city's cemetery possessed a commemorative stone (in addition to the policemen's graves) and commemorative rituals took place at the cemetery from the 1920 s well into the 1960s. While an emphasis on the loyal and dutiful sacrifices of the police played a key role in all of these commemorations, National Socialist influences at the ceremonies in the 1930s were obvious. Swastika flags, formations of the SA, the SS and the Hitler Youth, as well as representatives of the armed forces, had found their way to Hamburg in $1934 .^{70}$ In the Ruhr area commemorative rituals were linked to the fight against communists of the red Ruhr army in the early 1920s. While some monuments and commemorative plaques had already been unveiled in the Weimar years, others were erected in the Nazi period. Furthermore, state representatives and senior police officials made a point of attending these local ceremonies. ${ }^{71}$ In Bochum a monument was dedicated to "the policemen killed in the fight against

65 Der Deutsche Polizeibeamte, 15.10.1934, 20, pp. 764-65.

66 Ibid., p. 762.

67 Saehrendt (2004, pp. 142-45).

68 Photographs in Der deutsche Polizeibeamte, 01.02.1937, 3.

69 Photographs in Der deutsche Polizeibeamte, 01.07.1937; 13 Der deutsche Polizeibeamte, 15.08.1937, 6.

70 'Die Schutzpolizei Hamburg gedenkt ihrer im Kampf gegen den Kommunismus gefallenen Kameraden', Die Polizei, 20.11.1934, 22, pp. 460-61; 'Aus der Geschichte der Hamburger Polizei', Der deutsche Polizeibeamte, 15.01.1935, 2, pp. 46-47.

71 'Ehrung der Gefallenen der Essener Polizei', Der deutsche Polizeibeamte, 15.04.1934, 8, pp. $283-85$. BArch Berlin, R19/379, speech no.16 'Einweihung des Polizei Ehrenmals in Dortmund' 17.11.1935; R19/380, ‘Ansprache für die Gefallenen der Ruhrkämpfe in Bochum' 17.04.1937. 
communism as well as to the dead fighters of the Nazi party, the SA and the SS".$^{72}$ In this inscription, the police's fight against communism was again linked to the heroes of the Nazi movement.

Stressing the brutality, violence and maliciousness that allegedly characterised the communist fighters in their clashes with the police also served the purpose of justifying the National Socialists' actions towards the Communists after 1933. When the police journal Die Polizei reported in 1934 on commemorative events in Hamburg to remember those policemen who died at the communist uprising in 1923, the expression 'communist Untermenschen' was used. ${ }^{73}$ Kurt Daluege's speeches at the unveiling of the monuments in Bochum and Dortmund in 1935 and 1937 were filled with phrases like 'Jewish traitors', 'Bolshevik plague' and 'Bolshevik extermination'. Only through the sacrifices of the police, so Daluege claimed, had the country been saved. ${ }^{74}$

By the mid-1930s, police publications had created a narrative of historical reference points especially for 'heroic' deeds of the pre-1933 police. At the same time, old Nazis who had supported the National Socialist Party before 1933 and, often enough, had been in confrontations with the police protecting the Weimar State, were probably not convinced by the suggestion that they had common ground with policemen. Kurt Daluege hinted at this suspicion when he concluded a talk in October 1935 at a police training course with the words: “...I hope that by means of education we will eventually convince the last old fighter that the police officer of the previous system, who had often been an enemy of the national comrade in our years of struggle, has now become a friend and helper who does not want to be anything else but a national comrade himself in line with the Führer's will". ${ }^{75}$ Some areas of Germany had, until the mid-1930s, a force (the Feldjägerkorps) only recruited from the SS and the SA that dealt with order at Nazi Party events as well as with problems caused by SA men or 'old fighters'. This reflected the need to avoid a scenario in which a police officer was forced to arrest an SA man. ${ }^{76}$ This gives the impression that not everyone was convinced by the narratives created for the police, in spite of their strengthening by commemorative rituals that stressed the police's loyalty to the Führer.

With the outbreak of the Second World War, the inventing of past traditions and the stress on mutual enemies faded into the background. The focus shifted to the front and police journals now wrote of policemen who had died 'liberating Danzig'. ${ }^{77}$ In fact, Kurt Daluege tried hard, and probably in vain, when reminding his forces in 1941 that many policemen had lost their lives protecting the home front and that "these deaths counted as much as those in foreign territories" ${ }^{78}$ The

BArch Berlin, R19/389, (no page number), 8.4.1937.

73 'Die Schutzpolizei Hamburg gedenkt ihrer im Kampf gegen den Kommunismus gefallenen Kameraden', Die Polizei, 20.11.1934, 22, p. 460.

74 BArch Berlin, R19/379, Einweihung des Polizei Ehrenmals in Dortmund 17.11.1935; BArch Berlin, R19/380, Ansprache für die Gefallenen der Ruhrkämpfe in Bochum 17.04.1937.

75 Printed in Daluege (1936, p. 6).

76 Schmidt (2008, pp. 328-29).

77 Die deutsche Polizei, 15.10.1939, 19.

78 K. Daluege, 'Einleitung: Die Bewährungsprobe. Die Ordnungspolizei im ersten Kriegsjahr', Taschenkalender für die Schutzpolizei des Reiches u. Gemeinden u. Verwaltungspolizei 1941, p. 10. 
police monument and the one for Horst Wessel in Berlin did not survive the Second World War; both were melted down for resources. ${ }^{79}$ In fascist Italy initiatives of commemoration for the purpose of creating a common culture and tradition among policemen and fascists also took place. In contrast to the Nazi police, there is less evidence that any such initiatives were directly sponsored by the fascist government in the manner undertaken by the Prussian/Reich Ministry of the Interior, as described above. Indeed, some appear to have been taken from within the police institution (often by enthusiastic adherents to fascism) as a means of impressing upon the regime the fascist qualities of the police, particularly in the early years of fascist government.

In 1924, the task was undertaken of recording and publishing a list of 'martyrs' (martirologio) of the Interior Ministry Police, who had fallen in the course of their duties since national unification. The list was published in the 1924 and 1926 editions of the police journal, Il magistrato dell'ordine, directed by retired police chief (questore) and fascist enthusiast, Emilio Saracini. Indicating perhaps less of a focus on ideological enemies of the police than in the Nazi case, the list included officers and officials killed during civil and political disturbances, alongside those who lost their lives at the hands of thieves and brigands or as a result of accidental death, but also those who fell in circumstances which were hardly honourable for the force. Public Security Delegate Germano Bianchi was recorded as having died from wounds in April 1899, after being stabbed by an anarchist. ${ }^{80}$ Antonio Ricchiazzi, a member of the short-lived detective force (agenti investigativi), was entered on the list as having been shot and killed by an 'extremist' on 16 December 1920 while he was on duty at the Questura in Turin. ${ }^{81}$ The revised edition of the Martirologio della Polizia published in 1936 also remembered Questore Sebastiano Schillaci, who on 11 November 1929 was shot dead in his office by one of the Public Security officials under his command "in a moment of madness". 82

How exactly the rise of fascism determined the creation of the Martirologio della Polizia is unclear. Having begun on the initiative of police officials during a period in which the future role of the Interior Ministry police in the new regime was uncertain, partly because of ideological suspicions surrounding them, ${ }^{83}$ it suggests their desire to emphasise the institution's patriotic and professional qualities and reinforce the self-esteem of its members. We may speculate that such an initiative aimed to stress to police personnel, and possibly the new fascist government, a tradition of bravery and sacrifice which had hitherto been overlooked. The list may have attempted to publicize or invent qualities and values which policemen and fascists shared, particularly with reference to their battles against the Left during the period

Saehrendt (2004, p. 144).

80 'Martirologio della Polizia', Il magistrato dell'ordine, 1924, 1, p. 59.

81 'Martirologio della Polizia', Il magistrato dell'ordine, 1926, 3, p. 134.

82 'Martirologio della Polizia', Il magistrato dell'ordine, 1936, 13, p. 143.

83 Mussolini's initial demotion of the Interior Ministry Police is demonstrated by the abolition in December 1922 of its police corps, the Royal Guard (Guardia Regia), which was partly attributed to the corps' close association with previous Liberal governments. Only in 1925 did Mussolini decide to invest the Interior Ministry Police as the main police organ responsible for defending the regime, relegating the Carabinieri to rural areas and limiting the powers of the Party Militia. See Donati (1977, pp. 468-87). 
of the 'Biennio Rosso' ${ }^{84}$ There may also have been an element of imitation of fascist martirologi which commemorated squadristi who had fallen during the period of the ascendancy of fascism. ${ }^{85}$ The revision and re-publication of the Martirologio della Polizia, on 1 November 1936, ${ }^{86}$ may also reflect efforts on the part of Saracini and others to sensitize the fascist regime about what they saw as failure to give adequate public recognition to the 'sacrifices' of police personnel in comparison to the armed forces. This is evident in a feature in Il magistrato dell'ordine covering the 1936 celebrations of the Festa della Polizia, in which the editor hailed the event as an occasion for remembering the "martyrs, who had fallen in the course of their duties", and expedited the creation of the Interior Ministry Police's own commemorative monument in Rome - ensuring their equal status to the Carabinieri and other military forces. This is in striking contrast to the Reich Minister of the Interior's officiating at the unveiling of a police monument in Berlin which would become the locus for commemorative rituals and the Tag der deutschen Polizei, as described above. Whilst expressing confidence that the fascist government had already committed to this, the article noted that in the meantime members of the police could reflect upon their fallen colleagues in the revised Martirologio della Polizia which would shortly be published in the journal. ${ }^{87}$

The Festa della Polizia provided opportunities for rituals of joint commemoration at which the common values of personnel of the Interior Ministry Police and the Fascists were emphasised more explicitly. At the 1936 celebrations in La Spezia (Liguria), for example, a memorial chapel was opened at the police headquarters to honour two Public Security guards, Nunzio Calabresi and Carlo Rocchieri, who had been killed in 1921 in an armed conflict with 'subversives'. There followed a ceremony at the nearby cemetery, where the two guards' remains were buried, together with those of a fascist, in a common niche. A representative of the Chief of Police was also present at the ceremony. ${ }^{88}$ Such rituals of joint commemoration may have been inspired by the desire to build bridges between the old police and the new fascist state around the narrative of common sacrifices of fascists and policemen before Mussolini came to power. Yet, it is not clear from the available sources how representative such rituals were of Festa della Polizia celebrations held in other towns. Similar to the Nazi commemorations, these ceremonies appear to have been local initiatives. Did the police authorities 'tolerate' them or encourage them? We do not know whether they took place on the initiative of the police (or individual fascists within the police) or the local Party Federation, or as a result of close relations between the Party Federal and Questore.

The cementing of relations with the fascist regime (or formal representation of such) was also evident in acts of tribute which the police paid to fallen fascists. In June 1936, for example, as part of ceremonies marking the constitution of the Metropolitan Police of Naples, a delegation of police officials and platoon of officers

$84 \quad$ Although policemen and squadristi had often collaborated in oppressing the socialist movement in the years leading up to the March on Rome, such action was mainly illegal (often leading to punishment) and, therefore, never part of an official institutional discourse.

85 See Chiurco (1923).

86 'Martirologio della Polizia', Il magistrato dell'ordine, 1936, 13, pp. 136-43.

87 E. Saracini, 'La festa della polizia', Il magistrato dell'ordine, 1936, 13, pp. 133-34.

88 E. Saracini, 'La festa della polizia', Il magistrato dell'ordine, 1936, 13, pp. 133-34 (n.1). 
marched in procession to the local Fascist Party headquarters (Casa del Fascio). There followed a commemorative ritual in which two police officers, accompanied by the music of the fascist anthem 'Giovinezza' and in the presence of the other officers and young fascists, placed a laurel wreath at the foot of an altar in a memorial chapel. After a minute's silence, all those present raised their arms in the Roman salute, before signing a book of remembrance ${ }^{89}$ Though it is not clear from the available documentation on whose initiative or orders this ceremony took place, it is likely that memorial sites of fascist 'martyrs' became obligatory places of commemoration characterising major ceremonies involving the armed and police forces, alongside memorials to the fallen of the First World War. ${ }^{90}$

Although focused on fallen fascists, some of these commemorative events were an occasion for stressing the common ethos behind the work of police and fascist organisations. In May 1936, at the Caserta police training school, in the presence of the Chief of Police, Bocchini, the Commander of the Railway Militia, representatives from the armed forces and local dignitaries, the 10th Legion of the Railway Militia presented to the cadets a standard named after Michele De Carlo, a member of the Legion, killed on 9 April 1925 when confronting an armed gang of criminals. Before consigning the standard to the director of the school, the Militia Legion commander spoke of De Carlo's sacrifice and the "many affinities of direction" characterising the police and fascist institutions, "which often merge into the same heavy and delicate responsibilities, the same risks and the same sacrifices". This was followed by other speeches, which equally stressed the shared values of the two forces. For his part, Bocchini hailed De Carlo as a martyr and spoke of the Italian police which, "empowered by the prophetic spirit of the Duce, bows before the memory of the Blackshirt [De Carlo]". ${ }^{91}$

In the context in which police personnel faced relatively sparing ideological purges after Mussolini's rise to power, and in which recruitment and training procedures were never subjected to strict ideological control - in view of the autonomy which the police enjoyed from the Fascist Party - there is some indication that these rituals may have been interpreted by the Fascists, including police members among them, as a means of enhancing police identity with fascist ideology. But it is precisely because the Party was precluded from exercising a direct influence over police personnel that it is doubtful whether the culture which such practices of commemoration aimed to foster extended into daily working life, beyond the obligatory fascist salute (moreover, often ignored) and requirement to wear the Party badge. While from 1932 Party membership became obligatory for police personnel, after a ban on membership since the autumn of $1925,{ }^{22}$ there is little suggestion that fascists and the older generations of police personnel in service before 1922 were regularly encouraged or obliged to engage in activities which would help to nurture common values.

$89 \quad$ 'La 2a Divisione Speciale di Polizia a Napoli', Il magistrato dell'ordine, 1936, 13, pp. 62-63.

90 The inauguration of the Metropolitan Police of Naples began with a commemoration at the city mausoleum to honour those who had fallen in the First World War.

91 'Una simpatica cerimonia nella Scuola di Caserta e visita di S.E. Bocchini alla Questura di Napoli', Il magistrato dell'ordine, 1936, 13, pp. 63-64.

92 Given the obligatory nature of Party membership for all state personnel from 1932, it took on a strong meal-ticket characteristic. 
Undoubtedly, camaraderie developing between individual officers or officials and squadristi during the phase of the movement often lasted into the period of the dictatorship. More generally, like the Nazi Alter Kämpfer, first-hour fascists, together with leaders of the regime's organisations, felt little affection for the regular Italian police forces, which were considered ideologically wanting. At the level of the community - the locus for frequent tensions and rivalry between the Party and traditional institutions of the state - the fascist Militia resented the marginal role they were forced to play in policing, Party secretaries often clashed with the questori, and fascist youth and after-work leaders resented the supervisory powers of the regular police and Carabinieri over them ${ }^{93}$. On a more theoretical level, Party leaders were concerned that a 'fascist spirit' was not among the requisites for selection or promotion of members of the police, and resented the fact that police personnel were not allowed to join the Party-controlled Employee Associations (the ban was lifted and membership became obligatory in 1937). ${ }^{94}$

\section{CONCLUSION}

This article has analysed and compared the largely neglected ritualistic aspects of the regular police forces of fascist Italy and Nazi Germany, with a particular focus on the Italian Interior Ministry Police and the German uniformed police. Under Mussolini and Hitler, police festivities and commemoration rituals, incorporating the political iconography of the two regimes, allowed the fascist and Nazi dictatorships to showcase their police forces to the public as powerful organs of 'new' states; they contributed to a reinforcement of the image of/participation in the national community; in the context of competition and rivalry between a variety of police, armed and paramilitary forces, they enabled a particular institution to occupy public space and stress to both the public and the government that it was an indispensable security force; they were considered an important means of representing and nurturing the ideological integration of police forces associated with previous (enemy) regimes and building an institutional tradition and set of values which were at one with those of the fascist/Nazi movements.

Our comparison has revealed a number of differences regarding the forms which the festivities and rituals took and their management by the police authorities/ political regimes concerned. In particular, the Nazi Tag der deutschen Polizei seems to have involved more direct, practical and physical contact between the police and the public. This was partly a result of the development of the Tag der deutschen Polizei from similar celebrations during the Weimar Republic. The contrast with fascist Italy may also reflect Mussolini's particular emphasis on the spectacular and symbolic forms of political life. ${ }^{95}$ The Nazi rituals stressed the involvement of the police in fund-raising initiatives more than in the fascist case, reflecting broader differences of approach between the two regimes to the symbolic employment of

93 See Dunnage (2012, Chapter 3).

94 See R. Di Rienzo, 'Burocrazia problema di Stato', reproduced in Il magistrato dell'ordine, 1930, 7, 9, pp. 130-31, originally published in Il pubblico impiego, 14 July 1930, 4, 13, 1, p. 8; E. Lolini, 'L'iscrizione alle Associazioni fasciste', Le forze civili, March 1934, 4, 3, p. 1.

95 Falasca-Zamponi (2000, p. 10) argues that "it is the emphasis on form (intended as appearance, effects, orderly arrangement) that helps to explain fascism's cultural-political development." 
rituals of donation. The Festa della Polizia took place more regularly than the Tag der deutschen Polizei, and this is perhaps indicative of the lesser importance which the Nazi regime gave to this type of festivity or the lower status of the German police in relation to the military; by contrast, there is evidence that Mussolini personally assigned importance to the celebrations of an institution, the Interior Ministry Police, to which he had entrusted the main responsibilities for state security.

The documentation available also leaves the impression that the Nazi government was more pro-active than its Italian counterpart when it came to promoting the more intimate rituals which aimed to build a common culture between police officials and Nazis. It is telling that the Prussian Minister of the Interior should promote a 'golden book' of fallen policemen, when in Italy a similar initiative came from within the police, evidently to impress upon the new regime the ideological worthiness of a force which was discredited in the eyes of the new political masters. Even after the fortunes of the Interior Ministry Police took a turn for the better in 1925, the force's desire for a commemorative monument of its own still remained unfulfilled in the mid-1930s. It is, nevertheless, necessary to avoid overstressing differences characterizing these rituals, which, in our view, should be considered against an overriding commonality of aims and forms. Moreover, in several cases, there is insufficient documentary evidence from which to verify more general impressions of difference which have emerged from the study.

We are aware that in this article we have principally dealt with the ways in which the regimes of Mussolini and Hitler attempted to represent police forces (and their relationship with fascism/Nazism) both to the public and to their own personnel. We have focused on the strong element of manipulation and fabrication involved in processes of ideological integration behind the rituals studied. What is more difficult to ascertain is how successfully these strategies worked. It should be stressed, for example, that the public which the Festa della Polizia and Tag der deutschen Polizei targeted might have enjoyed the activities which featured during these events for a whole variety of reasons, which were not necessarily the same as those intended by the organizers. ${ }^{96}$ The sense of obligation to conform ideologically undoubtedly played a role in determining the attitudes of both policemen and the wider public, who, through participating, could demonstrate that they wanted to be part of the national community (or could communicate to others that they were good Nazi/fascist citizens).$^{97}$ Others might have liked the festivities because they were entertaining, especially for children. Many of the activities which featured in the German Tag der deutschen Polizei reflected how the police forces had tried to interact with the public before Hitler's rise to power, and this (rather than the political message behind them) could have appealed to members of the public and police alike..$^{98}$

Finally, if there is one further issue around which to consider a possible contrast between the two regimes, it relates to the question of how far they were able or desired to bring the culture which the rituals attempted to nurture into the everyday environments of the police station. It may well be that Hitler's regime, with its

96 Welch (2004, pp. 213-38) suggests that historians have to be careful not to equate the considerable efforts put into Nazi propaganda with its results. Bussemer (2000) also stresses the importance of looking at the reception of Nazi propaganda.

97 In regard to this aspect of rituals of donation, see Teerhoeven (2005, pp. 59-92).

98 Activities such as public concerts, sports competitions and showing police dogs and horses to children were (and still are) commonly featured in public image campaigns of the German police. 
tighter ideological control over the police - as exemplified by more rigid schooling in Nazi ideas and the, albeit slow, SS-ification of the police ranks - was better able to achieve this than the fascist regime, where the PNF were precluded from directly intervening in matters of recruitment and training. This could be one of the main focuses underlining further analysis of the ideological integration of police forces in fascist Italy and Nazi Germany.

Jonathan Dunnage
Department of History and Classics School of Arts and Humanities
Swansea University
UK - Swansea SA2 8PP
j.dunnage@ swansea.ac.uk
Nadine Rossol
Department of History
University of Essex
Wivenhoe Park Colchester
UK - CO4 3SQ
nrossol@essex.ac.uk

\section{REFERENCES}

Ackermann, V., Nationale Totenfeiern in Deutschland, Stuttgart, Klett-Cotta, 1990.

Aly, G., Der Jahrhundertprozeß. Erich Mielke, die Morde auf dem Berliner Bülowplatz und die deutsche Strafjustiz, in Jansen, C. et al. (eds), Von der Aufgabe der Freiheit. Festschrift für Hans Mommsen, Berlin, de Gruyter 1995, pp. 549-62.

Anon. Tausend Bilder: Große Polizei Ausstellung in Berlin, Berlin, Gersbach, 1927.

Behr, R., Cop culture. Der Alltag des Gewaltmonopols, Wiesbaden, VS Verlag, 2000.

Behr, R., Polizeikultur. Routine, Rituale, Reflexionen. Bausteine zu einer Theorie der Praxis der Polizei, Wiesbaden, VS Verlag, 2006.

Bernhard, P., Repression transnational. Die Polizeizusammenarbeit zwischen Drittem Reich und italienischem Faschismus, in Schulte, W. (ed.), Die Polizei im NS Staat, Frankfurt a.M.,Verlag für Polizeiwissenschaft, 2009, pp. 407-24.

Bussemer, T., Propaganda und Populärkultur. Konstruierte Erlebniswelten im Nationalsozialismus, Wiesbaden, DUV, 2000.

Chiurco, G.A., Fascismo Senese. Martirologio toscano dalla nascita alla gloria di Roma, Siena, Tipografia Combattenti, 1923.

Daluege, K., Tag der deutschen Polizei, Berlin, Eher, 1934.

Daluege, K., Stellung und Aufgaben der Polizei im Dritten Reich, Berlin, Kameradschaftbund deutscher Polizeibeamten, 1936.

Dams, C. et al. (eds), "Dienst am Volk ?" Düsseldorfer Polizisten zwischen Demokratie und Diktatur, Frankfurt a.M., Verlag für Polizeiwissenschaft, 2007.

Donati, L., La Guardia regia, Storia contemporanea, 1977, 8, 3, pp. 441-87.

Dunnage, J., Policing Right-Wing Dictatorships : Some Preliminary Comparisons of Fascist Italy, Nazi Germany and Franco's Spain, Crime, Histoire et Sociétés/Crime, History \& Societies, 2006, 10, 1, pp. 93-122.

Dunnage, J., Mussolini's Policemen. Behaviour, Ideology and Institutional Culture in Representation and Practice, Manchester and New York, Manchester University Press, 2012. 
Falasca-Zamponi, S., Fascist Spectacle. The Aesthetics of Power in Mussolini's Italy, Berkeley, University of California Press, 2000.

Gentile, E., Fascism as Political Religion, Journal of Contemporary History, 1990, 25, 2-3, pp. 229-51.

Gentile, E., Il culto del littorio. La sacralizzazione della politica nell'Italia fascista, RomaBari, Laterza, 1993.

Hansen, W., Zwischen Selbstdarstellung und Propaganda Aktion. Verkehrserziehungswochen und Tage der Deutschen Polizei als Beispiel der polizeilichen Öffentlichkeitsarbeit im NS Staat, in Buhlan, H., Jung, W. (eds), Wessen Freund und wessen Helfer? Die Kölner Polizei im Nationalsozialismus, Cologne, Emons, 2000, pp. 230-62.

Hermann, U., Nassen, U. (eds), Formative Ästhetik im Nationalsozialismus, Weinheim, Beltz, 1994.

Koschorke, H., Das Goldene Buch der deutschen Polizei, Jahrbuch der deutschen Polizei, Leipzig, 1936.

Loader, I., Policing and the Social: Questions of Symbolic Power, British Journal of Sociology, 1997, 48, 1, pp. 1-17.

Matthäus, J. et al. (eds), Ausbildungsziel Judenmord? "Weltanschauliche Erziehung" von SS, Polizei und Waffen-SS im Rahmen der "Endlösung”, Frankfurt a. M., Fischer, 2003.

Oliva, G., Storia dei Carabinieri. Immagine e autorappresentazione dell'Arma (1814-1992), Milan, Leonardo, 1992.

Reichel, P., Der schöne Schein des Dritten Reiches. Faszination und Gewalt des Faschismus, München, Hanser, 1991.

Rossol, N., Beyond Law and Order? Police History in Twentieth Century Europe and the Search for New Perspectives, Contemporary European History, 2013, 22, 2, pp. 319-30.

Saehrendt, C., Stellungskrieg der Denkmäler. Kriegerdenkmäler in Berlin der Zwischenkriegszeit, Bonn, Dietz, 2004.

Schloßmacher, N., "Kurzerhand die Farbe gewechselt". Die Bonner Polizei im Nationalsozialismus, Bonn, Stadtarchiv Bonn, 2006.

Schmiechen-Ackermann, D. (ed.), Volksgemeinschaft: Mythos, wirkungsmächtige soziale Verheißung oder soziale Realität im Dritten Reich?, Paderborn, Schöningh, 2012.

Schmidt, D., Schützen und Dienen. Polizisten im Ruhrgebiet in Demokratie und Diktatur 1919-1939, Essen, Klartext, 2008.

Schulte, W. (ed.), Die Polizei im NS-Staat, Frankfurt a.M., Verlag für Polizeiwissenschaft, 2009.

Tennsted, F., Wohltat und Interesse. Das Winterhilfswerk des Deutschen Volkes: Die Weimarer Vorgeschichte und ihre Instrumentalisierung durch das NS Regime, Geschichte und Gesellschaft, 1987, 13, pp. 157-80.

Terhoeven, P., "Nicht spenden, opfern". Spendenkampagnen im faschistischen Italien und im nationalsozialistischen Deutschland als Disziplinierungs- und Integrationsinstrument, in Reichardt, S., Nolzen, A. (eds), Beiträge zur Geschichte der Nationalsozialismus. Faschismus in Italien und Deutschland, Vol. 21, Göttingen, 2005, pp. 59-93.

Vondung, K., Magie und Manipulation. Ideologischer Kult und politische Religion des Nationalsozialismus, Göttingen, VR, 1972.

Weinhauer, K. Polizeigeschichte vom Zweiten Weltkrieg bis in die Bundesrepublik. Anmerkungen zu einigen Neuerscheinungen, IWK, 2003, 39, pp. 378-83.

Welch, D., Nazi Propaganda and the Volksgemeinschaft: Constructing a People's Community, Journal of Contemporary History, 2004, 39, pp. 213-38.

Wildt, M., Volksgemeinschaft als Selbstermächtigung. Gewalt gegen Juden in der deutschen Provinz 1919-1939, Hamburg, HIS Verlag, 2007. 